\title{
PORTUGUÊS COMO SEGUNDA LÍNGUA: CONTRIBUIÇÓES PARA A IMPLANTAÇÃO DE UM PROGRAMA DE ENSINO BILÍNGUE PARA SURDOS
}

RIBEIRO, Tiago; SILVA, Aline Gomes da (Orgs). Leitura e escrita na educaçáo de surdos: das políticas às práticas pedagógicas. Rio de Janeiro: Editora Wak, 2015. 211 p.

Leitura e escrita na educação de surdos: das políticas às práticas pedagógicas é uma obra de 211 páginas, dividida em 8 (oito) capítulos e organizada por Tiago Ribeiro e Aline Gomes da Silva, lançado em 2015, pela Editora Wak. Os textos que compóem a organização reúnem diferentes intelectuais que vêm, ao longo dos últimos anos, dedicando-se à literatura surda. Os artigos chamam atençáo para os conceitos de alteridade e a diferença na Educação de Surdos. Como ideia principal, os autores sustentam que a surdez náo pode ser encarada como deficiência e sim como existência, singularidade. Reforçam, sobretudo, a argumentação de se pensar a diferença a partir da diferença. Sendo assim, colocam questôes que interrogam sobre a dificuldade de aprendizagem dos sujeitos surdos, em relaçáo à leitura e à escrita. Quais as dificuldades que os estudantes surdos apresentam no ato de ler e escrever? Quais as outras possibilidades de se pensar leitura e escrita no cotidiano da escola, no bojo da Educação de Surdos?

No primeiro texto, Ensaios de pesquisa sobre políticas da Educação de Surdos: entre o maior e o menor da educação, Luma Cordeiro e Anelice Ribeiro, no panorama das propostas oficiais, analisam as políticas públicas no contexto da Educação de Surdos. Indagam em qual medida tais políticas contemplam a diversidade do cotidiano de sujeitos surdos.

Em seguida, Aline Gomes da Silva, no texto Oficina de Leitura: uma proposta bilíngue para a formação de leitores surdos, descreve uma relevante experiência no Colégio de Aplicação do Instituto Nacional de Educação de Surdos (CAP-INES), a qual coloca como autores e produtores, de suas 
próprias experiências, alunos e alunas do Colégio.

Simone Silva, no artigo Consequências da aquisição tardia da Lingua Brasileira de Sinais na compreensão leitora da Lingua Portuguesa como segunda lingua, em sujeitos surdos, relata a importância de se aprender língua de sinais e também língua portuguesa na modalidade escrita para os estudantes surdos, destacando a necessidade do contato do sujeito surdo com a língua de sinais desde a tenra idade.

A seguir, Tiago Ribeiro, Edivana Santos e Luciana Furtado, no texto Reflexôes sobre a leitura e escrita na educação bilíngue de surdos, destacam como se tem deixado de discutir as especificidades culturais e linguísticas no processo de ensino- aprendizagem de alunos surdos, isso impossibilita discussōes a respeito da alfabetização na educação de surdos.

$\mathrm{O}$ artigo Prática de leitura literária e hibridismo cultural em um contexto de jovens $e$ adultos surdos, de autoria de Alessandra Gomes e Vanderléa Oliveira, traz à tona a experiência de uma Oficina de Literatura com estudantes da Educação de Jovens e Adultos Surdos, potencializando a discussão sobre os diferentes gêneros textuais.

No texto $A$ relaçáo dos surdos com a língua Portuguesa em um contexto bilíngue, Bruna Neves e Ronice Quadros trazem entrevistas que relatam sobre a importância da aprendizagem da Libras e das metodologias singulares que levam em consideração as particularidades dos sujeitos surdos, na busca de um melhor desempenho na aprendizagem da Língua Portuguesa.

A autora Marise Porto, no artigo "Ai, eu olho, escrevo e aprendo": narrativas de estudantes surdos sobre aprendizagem e ensino da Lingua Portuguesa (escrita) no Colégio de Aplicação do Instituto Nacional de Educação de Surdos, relata como tem sido percebida a importância da aprendizagem do Português (escrito), por meio das narrativas das experiências dos próprios alunos do Colégio de Aplicação.

Por último, mas não menos importante, Daniele Moura compartilha suas ideias no artigo intitulado: Entre dois mundos - a experiência do Sarau Bilíngue e a contribuiçấo para o desenvolvimento de práticas de letramento em segunda lingua para surdos e ouvintes. A autora descreve como desenvolveu a ideia do Sarau Bilíngue, no contexto de um curso de Pedagogia, para surdos e ouvintes. O texto aborda a importância do debate sobre bilinguismo na formação de futuros pedagogos e professores.

Em síntese, a leitura do livro supracitado remete ao conceito de Diferença, sobretudo de diferença e educaçáo de surdos. A partir da análise dos 
textos, percebe-se que é necessário promover uma virada, um deslocamento, uma renovação dos quadros teóricos que ocupam a escola desde sempre. Se as discussóes sobre diferença atravessam momentos de questionamentos, então estes precisam acontecer na escola, na universidade e, também, na sociedade. Essa turbulência de mudanças, trazida com o debate sobre a diversidade, pressiona velhas estruturas do sistema educacional brasileiro.

As necessidades do século XXI requerem cidadãos que sejam culturalmente sensíveis e internacionalmente focados. Com as mudanças, além de adquirir uma diferente visão de mundo, obtém-se também uma linguagem para nomear esse novo mundo que também se transforma. Palavras antigas ganham novos significados e as novas são absorvidas ao vocabulário, resultando em outra maneira de enxergar a realidade. O olhar para diversidade que abarca a Educação de Surdos se faz urgente.

Debater a proposta do livro, sobre o tema da diferença na e para Educação de Surdos, significa trazer algumas indagaçóes: como planejar, organizar e aperfeiçoar práticas de uma educação que contemplem o ambiente bilíngue de aprendizagem para surdos? Que açôes concretas são necessárias à Educação de Surdos? Quais propostas e metodologias diferenciadas serão ofertadas no cotidiano de alunas e alunos surdos?

Diante de tais questôes, cabe dizer que a Educação de Surdos pressupóe reconhecer o pluralismo e a diversidade como elementos-chave da realidade complexa; significa contribuir para a construção de açóes coletivas nas organizaçôes de ensino. Ao perceber a surdez como diferença, caminhase para o conhecimento de respostas para a questão da diversidade, seja ela local ou global.

É urgente avançar em respostas para uma Pedagogia da Diferença voltada para o reconhecimento das açóes democráticas, em que a identificação das diferenças e o rompimento com os procedimentos discriminatórios se configuram em açóes essenciais para Educação.

O fato de se trabalhar com vozes plurais vem ao encontro da necessidade de se contemplar a Pedagogia da Diferença não só em conteúdos pesquisados, mas como estratégia de pesquisa que se questione a si própria e fuja de discursos dominantes. Nesse sentido, é perceptível, nos escritos dos autores, a necessidade de se estabelecer debates, discussóes das temáticas que envolvem os marcadores identitários plurais constituídos de raça, etnia, gênero, classe social, cultura, linguagem e outros determinantes que se interagem e contribuem na formação de identidades individuais, coletivas e institucionais. 
O contexto atual exige uma compreensão ampliada das práticas educativas. Há de se pensar em uma Pedagogia da Diferença que investigue os objetivos sociopolíticos e os meios metodológicos de viabilizar os processos formativos em contextos socioculturais específicos, levando em consideraçáo que as práticas educativas ocorrem em diversos lugares, em instâncias formais, não formais, informais, ou seja, acontecem nas famílias, nos locais de trabalho, na cidade, na rua, nos meios de comunicaçáo e, também, nas instituiçôes.

É evidente que um dos principais problemas em se confrontar a sociedade atual é defrontar-se com a hostilidade em relação às diferenças, à insensibilidade cultural e linguística, assim como a tradição intolerante para com o diferente. Em tempos de pluralismo cultural, a Pedagogia da Diferença é necessária para lidar com a diversidade. Em sua essência, não é nada mais do que a arte de gerenciar as diferenças de maneira qualitativa. Consiste em uma alternativa para educadores e gestores, nas escolas e nas universidades, nas organizaçóes, principalmente, na organização curricular.

A partir da leitura do livro - Leitura e Escrita na Educação de Surdos: das políticas às práticas pedagógicas, entende-se que a Educação de Surdos deve estar pautada na habilidade de dialogar com o outro, com todas as possibilidades e alternativas que depreendem desse diálogo, no horizonte da transcendência de barreiras e do fomento à unidade em meio à diversidade. O educar para e com a diferença capacita no que diz respeito a considerar o outro, especialmente, o outro, cuja sociedade ensinou a enxergar com desconfiança, suspeita e preconceito.

A Pedagogia da Diferença possibilita reconhecer as semelhanças entre os indivíduos a partir de suas diferenças culturais, sociais e raciais. Os profissionais de educação, que respeitam e consideram a diferença como uma possibilidade, dáo um passo à frente na luta contra a opressão e a discriminação. Esse reconhecimento é o ponto de partida para o comprometimento com os ideais democráticos em consonância com a dignidade humana, a justiça e a equidade.

É importante ressaltar que, por razóes políticas, sociais, educacionais e econômicas, é necessário reconhecer as instituiçóes de ensino como organizaçôes culturalmente diversas. Nesse sentido, a Pedagogia da Diferença é para todos. É, também, encorajar os atores educacionais a terem papéis atuantes em seu próprio desenvolvimento educacional e institucional, levando suas histórias e experiências para o escopo do ensino e do aprendizado, desenvolvendo atitudes positivas sobre diferentes grupos 
de pessoas e aprendendo como avaliar o conhecimento a partir de diferentes perspectivas.

É, enfim, contribuir para o desenvolvimento de identidades institucionais positivas e para um clima de valorização das diferenças, sustentando habilidades de poder de decisão e de análise crítica no contexto da pluralidade - centrais no mundo globalizado e culturalmente diversificado. Portanto, a obra organizada por Tiago Ribeiro e Aline Gomes da Silva é necessária e fundamental para se compreender melhor o universo da Educaçáo de Surdos. 